\title{
Electron microscopic studies of the parafollicular cells in the thyroid gland of the dog
}

\author{
By \\ Masaharu Tashiro \\ Department of Anatomy and 1st Department of Surgery, \\ Nagoya University School of Medicine \\ (Directors: Prof. Dr. Shooichi Sugiy a ma and \\ Prof. Dr. Yoshio Hashimoto)
}

\section{Introduction}

Histological studies of parafollicular cells, in relation to their differentiation and significance, have often been repeated in different mammals ( $\mathrm{T}$ akagi, '22, in dogs; $\mathrm{R}$ a y mond, '32, in rabbits ; $\mathrm{N}$ on ide $\mathrm{z}$, '32, in dogs; $\mathrm{Sug}$ i y a ma, '39, '42, '50 and '54, in rodents ; B a rg m a $\mathrm{n}$, ' 39 ; $\mathrm{S}$ a it o, '56, in rats and $\mathrm{S}$ a to, '59, in hamsters) but the results obtained have been varied and remain unsettled. The situation has called for increased attention, and histochemical and experimental observations have recently been started on them ( $\mathrm{S}$ a r k a r, '61, in rats; G a b e, '61, in sauropsides and amniotes; $\mathrm{Gabe}$, '59, in dogs; $\mathrm{Stux}$ et al., '61 in rats; $\mathrm{Dum}$ o $\mathrm{t}$, '58, in rabbits). Notwithstanding this current interest, little work has been done on electron microscopic studies. I r i e ('60) found parafollicular cells in cattle by electron microscopy. Yos him u ra et al. ('62) studied rats under different experimental conditions and noted their presence also by the same method.

For the above reason, the author undertook the present study with the object of filling the gaps in knowledge and presenting some new evidence on the parafollicular cells of dogs by electron microscopy, and discussed their differentiation and significance by comparing the present results with previous data regarding them.

\section{Materials and Methods}

Fourty dogs consisting of puppies shortly after birth and adults one to three years old were used and divided into two series, control 
and experimental. In the control series, 22 were sacrificed by a sharp blow at the base of the skull and exsanguinated via a thoracic incision. In the experimental series, 18 received single subcutaneous injections of 2 units (2 Meerschweincheneinheiten, $\mathrm{J} \mathrm{un} \mathrm{km}$ a n nSchoeller) per $100 \mathrm{~g}$ body weight of thyroid stimulating hormone (Pretiron Schering) and were sacrificed at intervals of 1, 2, 3, 12 and 24 hours in the same manner as in the control series.

The thyroid glands of the two series were removed immediately after sacrifice and divided into two halves. One half were cut into small pieces for electron microscopy, and the pieces were fixed in $\mathrm{P}$ a I a d e's fluid (1\% solution of osmic acid buffered with veronal acetate to $\mathrm{pH}$ 7.4). After fixation for one hour, some of the pieces were dehydrated with ethanol, embedded in epoxy resin (Epon 812, Epon $815, \mathrm{DDSA}$ ) polymerized at $50^{\circ} \mathrm{C}$ under the influence of pyridine ( $\mathrm{K}$ us hid a's method, '59) or embedded in Araldite by G la uert's method, and the other embedded in methacryrate. Some were dehydrated with acetone and embedded in polyester resin polymerized at $55^{\circ} \mathrm{C}$ under the influence of benzoyl peroxide paste according to $\mathrm{K}$ u shida's method ('60). Ultrathin sections were cut with glass knives on a microtome model JUM 5 type. The specimens made were stained for different hours $(1,2,4,12$ and 24 hours) with one of the following staining solutions: those saturated with lead acetate, lead hydroxide, and uranyl acetate, and 1\% potassium permanganate solution. The specimens were photographed at initial magnifications of 1,000 to 7,000 in diameter by use of an electron microscope model JEM $5 \mathrm{G}$ type and subsequently further enlarged. The other halves of the thyroid glands were also cut into pieces for routine histological observation. Some were fixed in Helly's or Ciaccio's fluid, and 6 to $8 \mu$ sections prepared were stained with hematoxylin and eosin or with $\mathrm{H}$ e i d e $\mathrm{n} h$ a i n's azan and periodic acid-S $\mathrm{c} \mathrm{h}$ if $\mathrm{f}$ 's technique. Others were fixed in $\mathrm{Kols}$ ter's fluid and the 6 to $8 \mu$ sections were stained with $\mathrm{H}$ e ide $\mathrm{n}$ hai n's iron hematoxylin.

\section{Observations}

Light Microscopy: Control Series. Follicle cells were cubical and had round to oval nuclei. The chromatin reticulum was moderately dense. The nucleolus was relatively prominent but smaller than that of parafollicular cells. Preparations fixed in Kolster's fluid and stained with $\mathrm{H}$ e ide $\mathrm{n}$ ha in's iron hematoxylin indicated that follicle cells can be classified into two kinds, clear and dark follicle 
cells. The clear follicle cells contained a number of filamentous and rod-shaped mitochondria generally lateral to the nuclei and sometimes a few colloid droplets and vacuoles. The colloid droplets were well demonstrated with periodic acid-Schiff's stain. The dark follicle cells had a few mitochondria and rarely colloid droplets. Some slender dark follicle cells corresponded with so-called L a n g e nd o r f's colloid cells. With periodic acid-S c h if f's stain, dark follicle cells were stained intensely reddish purple.

Parafollicular cells were of different sizes and round to oval, or sometimes polygonal in shape, but larger than ordinary follicle cells (fig. 1). They did not grow significantly with increase in age and were on the average 14 to $10 \mu$ in the long diameter and 12 to $9 \mu$ in the short diameter. The nuclei were round to oval, sometimes irregular-shaped, and larger than those of follicle cells, with diameters of 9 to $7 \mu$ and frequently were eccentrically located. They had generally a finer chromatin reticulum and a more prominent round nucleolus (fig. 1). In routine preparations, the majority of parafollicular cells were generally so chromophobic and pale that rendered them readily distinguishable from follicle cells. Periodic acid-S $\mathrm{c}$ h if $f$ 's stain did not impart a special staining intensity different from that of follicle cells, but the cytoplasm was generally very slightly more reddish purple than of follicle cells. The tone of the color remained unchanged by saliva digestion. They had no colloid droplets. In preparations fixed by $\mathrm{Kolster}$ 's fluid and stained with $\mathrm{H}$ eiden hai n's iron hematoxylin, the parafollicular cells were classified into two kinds, clear and dark parafollicular cells. In the cytoplasm of both, dust-like tiny particles including small granular mitochondria were more or less sparsely distributed. The dark parafollicular cells were found in small numbers and contained sometimes numerous particles.

The parafollicular cells did not border the follicle cavity directly, being located on follicle walls as single elements or in groups, but rarely bordered the follicle cavity. When in groups, they gathered together as compact buds and plates, surrounded in a set with follicles by argyrophilic fibers and perifollicular capillaries (figs. 1). In these groups, some parafollicular cells often showed no nucleus. With cells of great size it can be expected that many sections will occur in which nuclei are not visible. Some of the parafollicular cells were in a stage of degeneration, showing pyknotic nuclei and some showed mitotic division.

Experimental Series. Routine preparations showed that follicle 
cells retain their original shape but are enlarged and become domeshaped at the apical margin. The nuclei increased in size too. The cytoplasm came to contain numerous colloid droplets which were especially well demonstrated with periodic acid-S ch iff's stain. Preparations fixed in Kolster's fluid and stained with $\mathrm{Heiden-}$ $\mathrm{h}$ a i n's iron hematoxylin indicated that follicle cells have abundant filamentous mitochondria, increase of vacuoles and numerous colloid droplets with different staining intensity. But this change was of short duration. They returned to a nearly normal appearance, with decrease in colloid droplets, within 12 to 24 hours after the injection.

On the other hand, parafollicular cells indicated no significant change, retaining their original shape and condition, and appeared singly or in groups, containing no colloid droplets. They bordered directly the follicle cavity as rarely as in the control series. In preparations fixed in $\mathrm{Kols}$ te r's fluid and stained with $\mathrm{H}$ e i de nha in's iron hematoxylin, the majority of parafollicular cells were chromophobic and pale, and the minority dark. No increased mitotic division nor enhanced degeneration were seen.

Electron Microscopy. Control Series. The findings found by light microscopy were almost the same as those observed by electron microscopy. Many parafollicular cells were far less electron dense than follicle cells, and seen singly or in groups, as clear large cells directly located upon follicle cells in parafollicular and interfollicular positions (figs. 2 and 4). They were usually found separated from the follicle cavity by a thin layer of the cytoplasm of the follicle cells (fig. 2), but very rarely bordered directly the follicle cavity. They were generally oval to round (fig. 4) but polygonal when in groups (figs. 2 and 3). Narrow homogeneous intercellular spaces bounded by the adjacent plasma membrane were visible in between and at places where they were in contact with follicle cells, but had no desmosomes and no tortuous interdigitations (figs. 2 to 5). In other places where they were partly surrounded by argyrophilic fibers and perifollicular capillaries, there were found epithelial basement membranes. (fig. 3). The basement membranes continued, without showing special structure and changes, to those of the follicle cells. Beneath these basement membranes, fine fibrils of argyrophilic fibers and the basement membrane of the endothelial cells of capillaries were found. The plasma membrane found here did not form basal infoldings (fig. 3). The spaces between the plasma membrane and basement membrane were continuous with the intercellular spaces. These parafollicular cells were identified as clear 
forms which represented the majority of this kind of cell.

The nuclei were round to oval and sometimes irregular-shaped, and always more or less eccentrically located (figs. 2 to 4). They were moderately filled with electron dense granular material which showed an usual distribution. Further, several aggregates of more densely packed granules were found here and there. The nuclear membrane presented a hair-line appearance and could be resolved to be double. The outer membrane sometimes extended to form the beginning of the rough-surfaced endoplasmic reticulum. The nucleolus was prominent with a round glomerulus and consisting of anastomosing cords of densely packed granular material near the periphery of the nucleus.

The Golg i complex was well-formed and seen near the nucleus (figs. 2 to 5). It was similar in many respects to that observed in the epididymidis of mice by $\mathrm{D}$ a $\mathrm{l}$ to $\mathrm{n}$ and $\mathrm{Fel} \mathrm{ix} \mathrm{('54).} \mathrm{It} \mathrm{consisted}$ of arcuated thin lamellar sacs, numerous vesicles and vacuoles. Some of the vesicles were electron dense (figs. 3 and 5).

One of the most significant characteristics of parafollicular cells was the poor development of the rough-surfaced endoplasmic reticulum (figs. 2 to 5). It was more or less extensively dispersed in the form of small vesicles throughout the cytoplasm and sometimes appeared as a few or several thin lamellar sacs together with these vesicular forms. The vesicular forms appeared usually empty, but sometimes contained homogeneous material similar in density to follicle colloid but at times more so. These vesicular forms were generally smaller near the G o l g i complex. The endoplasmic reticulum, vesicular and lamellar in form, was always associated with tiny electron dense RNP granules which had somewhat more uneven distribution than those of follicle cells. There were no smoothsurfaced forms of endoplasmic reticulum.

Mitochondria were smaller in size and fewer in number than of follicle cells (figs. 2 to 4). They showed often round to shortly oval, and rarely rod-shaped, partly branched profiles, which were not smooth but rather characterized by the ruffled outline of the double membrane (figs. 3 and 5). They had a proper internal structure, cristae mitochondriales, as has been described in various tissues of rats by Palade ('52). The cristae mitochondriales were arranged relatively closely but irregularly, not always perpendicular to their long axes. These mitochondria displayed no particular orientation and concentration in the cell body but rather appeared to be randomly distributed. These findings of the mitochondria 
were also one of the characteristics that help differentiation from follicle cells.

Besides RNP granules associated with the endoplasmic reticulum, there were groups of free RNP granules not associated with the endoplasmic reticulum, dispersed randomly in the cytoplasm (figs. 2 to 5). Two other kinds of granule were also contained in the cytoplasm. One of the granules was finely stippled (figs. 2 to 5). They were far less electron dense, less defined than RNP granules, and dispersed in a rather random fashion throughout the cytoplasm. They corresponded in appearance with the precipitated amorphous substance of the ground cytoplasm. The other type of granule was round to oval in shape and of different electron density and size. They were secretory in nature (figs. 2 to 5 ). The granules varied in size from $40 \mathrm{~m} \mu$ to $300 \mathrm{~m} \mu$. They were found limited by a welldefined membrane and always smaller in size in the area of the Golgi's complex. They corresponded with some of the dust-like particles observed by light microscopy and varied more or less in number from cell to cell.

Experimental Series. After the injection of thyroid stimulating hormone parafollicular cells exhibited no significant change, or if any, very slight dilation of the rough-surfaced endoplasmic reticulum (figs. 7 to 10). The mitochondria showed almost the same appearance as that found in the control series - with ruffled outlines of the double membrane and irregularly arranged cristae mitochondriales (fig. 10). Secretory granules were found less numerous than might be expected and showed no significant difference in number and size from those of the control series. No intermediate forms between the parafollicular cells and follicle cells occurred in this experimental series. Rarely, parafollicular cells had numerous vesicular forms of endoplasmic reticulum in one half of the cell body and thin lamellar forms in the other half (fig. 7). On the other hand, follicle cells indicated marked change of the rough-surfaced endoplasmic reticulum (fig. 6). The endoplasmic reticulum was greatly increased in size and so dilated that they occupied the greater part of the cytoplasm.

Dark parafollicular cells which were seen well by the light microscope were identified with difficulty by electron microscopy. A number of cells with numerous rod-shaped and oval mitochondria, as well as a number of secretory droplets and relatively welldeveloped rough-surfaced endoplasmic reticulum were found near the ordinary follicle cells, and they were supposed to be dark 
parafollicular cells. An exact identification of the cells by electron microscopy is presently being attempted.

\section{Discussion}

A survey of the literature reveals various controversies concerning the origin, significance and fate of parafollicular cells. Theyin a broad sense-seem to include various categories (interfollicular cells, macrothyrocytes, argyrophilic cells, nh-cells, clear gland-like cells and light cells) of cells or their groups which are found between follicles or directly on the follicle cells and further wedged between them. Their nuclei have been described to be slightly larger than or as large as those of follicle cells and their clear cytoplasm has been reported to contain argyrophilic granules. Some have included also another kind of parafollicular cell with dark cytoplasm seen in rodents ( $\mathrm{S} \mathrm{u} \mathrm{g}$ i y a m a, '39 in rats ; '50, in rabbits ; '54, in guinea pigs).

On the other hand, a number of authors have denied their occurrence and regarded them merely as tangential sections of follicles. (W i l s o n, '27/28, in man; L u d w i g, '53, in rats, guinea pigs and dogs) or as the earliest stages of a beginning indirect cell division ( $\mathrm{Ludwig}$, '54, in rats and dogs). Bargmann ('58) found in primates that the cell groups seen in the interfollicular tissue are embodied in sections of solid and hollow buds of large follicles. Recently, E hre n brand (54), in the thyroid gland of guinea pigs activated by the administration of thyrotrophic hormone, found that the parafollicular cells represent a mitotic form and partly a highly active stage of follicle cells. Gabe ('59, in dogs; ' 61 , in sauropsides and amniotes) also found, by histochemical methods including periodic acid-S $\mathrm{ch}$ if f's stain, a similar finding that the parafollicular cells represent a stage in the evolutionary process of the principal cells and not an independent cell category. Vo itk e vitch ('63, in puppies) expressed a similar view. The present results comfirmed accurately the occurrence of parafollicular cells as an independent cell species by electron microscopy. (figs. 1 to 10 ).

The problem of the origin of parafollicular cells has been differently discussed. A few (D e m p s e y, '54) considered them to be argyrophilic connective tissue cells which migrate in between the follicle cells. Some stated that they are of embryonic nature (W öl fler, 1880) or residual cells of the embryonic thyroid gland (Bozzi, 1895). Isenschmid ('10, in infants) found the inter- 
follicular cells to occur through depletion of colloid in the follicles, and similarly B e r n a r d ('27, in dogs) observed them to be cells of the follicles compressed after depletion of colloid. S a n d e rs on$\mathrm{D}$ a $\mathrm{mberg}$ ('11, in man) and Feyrter ('53) reported that they develop from the budding process in the follicle walls. Florent in and Grujic ('29, a, b; '30) found in guinea pigs that the epithelial islets found between the follicles arise from the follicle walls through amitotic division. Non idez ('32 a, in dogs ; ' 33 , in mammals) and $\mathrm{R}$ a y mon $\mathrm{d}$ (' 32 , in rabbits) found that the parafollicular cells occur in the follicle walls, and migrate from here towards the interstitium. O h k u bo ('35, in dogs) and $\mathrm{S} \mathrm{u} g$ i y a $\mathrm{ma}$ ('39, in rats; ' 50 , in rabbits) described the parafollicular cells to develop from the follicle cells. S u g i y a m a ('54), in the histogenesis of the same gland of guinea pigs, found again that the parafollicular cells differentiate from the follicle cells. S a n d it te $\mathrm{r}$ and $\mathrm{Kl}$ e in ('54) found two kinds of argyrophilic cell, one the parafollicular cell of $\mathrm{Nonidez}$ and the other the interstitial cell, a special type to be distinguished from the former. The ovoid cells of Bensley ('14, in opossums) are supposed to be included in the category of parafollicular cells. On the other hand, Godwin ('37) identified gray cells-unorganized cell masses of ultimobranchial origin in the thyroid gland of dogs-with parafollicular cells. V a n D y k e ('45) found two kinds of interfollicular cells in young sheep-one developing from the follicle cells of broken follicles and the other of ultimobranchial origin. Similarly, K r o o n ('58) reported in rats and rabbits that the macrothyrocytes are always found in the thyroid gland with forming microfollicles and arise from both the follicle walls and the mucus secreting branchiogenic tissue contained in the thyroid gland. The neuro-hormonal cells (nh-Zellen) also may represent a category of parafollicular cells and have been reported to be found numerously in or around the follicles of the activated thyroid gland migrating from the thymus through the hilus (S under-Plas smann, '39 a,b.c,). Stux et al. ('61, in rats) described the parafollicular cells as light cells which originate possibly from follicle cells, and considered them to be a cell species on its own right.

The present observations suggested at the electron microscopic level that the parafollicular cells are completely different in fine structure from the follicle cells and further no intermediate forms between the parafollicular cells and follicle cells are found (figs. 1 to 5). The administration of thyroid stimulating hormone does not 
lead the follicle cells to develop into parafollicular cells and inversely the parafollicular cells to return to the follicular cells. The cytoplasmic organelles of the parafollicular cells do not show any reversible change at the electron microscopic level (figs. 6 to 10).

In agreement with some of the data of God w in ('37, in dogs) and $\mathrm{V}$ a $\mathrm{n} \mathrm{D} \mathrm{y} \mathrm{ke} \mathrm{('45,} \mathrm{in} \mathrm{sheep),} \mathrm{recently} \mathrm{D} \mathrm{u} \mathrm{m} \mathrm{o} \mathrm{n} \mathrm{('56,} \mathrm{in} \mathrm{rabbits)}$ expressed that the parafollicular cells are distributed around the remnants of the thyroglossal duct, from which they take their origin and he ('58, in rabbits) stated further that they are derived from the 4 th branchial cleft. The present author ('63) previously published the interesting fact that may partly confirm their description-the epithelial cells of the ultimobranchial cyst found in the thyroid gland of dogs resemble in fine structure the parafollicular cells, viz., both kinds of cell contain poorly developed rough-surfaced endoplasmic reticulum (generally vesicular in form and rarely thin lamellar) and a number of short oval or round mitochondria (figs. 1 to 10 ). These results are of some value as they lead to a conclusion that the parafollicular cells and the epithelial cells of the ultimobranchial cyst may develop from a common origin.

The problem concerning the significance of the parafollicular cells has also been the subject of discussion. Some considered them to be secreting cells (B e $\mathrm{n} \mathrm{sl}$ e y, '14, in opossums; $\mathrm{T}$ a k a g i, '22, in dogs ; O h k u bo, '35, in dogs; Arimitsu, '37, in rats; $\mathrm{Sug}$ i y a ma, '50, '54, in rabbits and guinea pigs). Recently, S a to ('59) described in hamsters that the parafollicular cells represent a kind of secreting cell because of their close proximity to capillaries but are not capable of playing an important role because of their derivation from the ultimobranchial body which degenerates. This view was further confirmed by periodic acid-S chiff's staining. With this stain, the parafollicular cells of dogs contain no secretory droplets which resemble in staining colloid droplets found in the follicle cells. $\mathrm{Kr}$ o o $\mathrm{n}$ ('58, in rabbits and rats) demonstrated the formation of mucopolysaccharides and their granules in the macrothyrocytes by the same method. However, it was indicated in the preparations fixed in Kolster's fluid and stained with $\mathrm{H}$ eidehain's iron hematoxylin that the parafollicular cells have more or less dust-like particles including granular mitochondria. Some of the particles are demonstrated to be secretory granules by electron microscopy and to be produced in the $\mathrm{G} \mathrm{ol} \mathrm{g}$ i complex in a pattern similar to that found in the follicle cells ( $\mathrm{T}$ a s h i r o, '62, in dogs). Conclusively, in general agreement with the data of $\mathrm{St} u \mathrm{x}$ et al. ('61, in rats), 
the present data indicated by the use of periodic acid-S chiff's stain that the parafollicular cells are not responsible for thyroid stimulating hormone by producing numerous colloid droplets, and showed at the electron microscopic level that the secretory granules and further other cytoplasmic components are not influenced by thyroid stimulating hormone (figs. 6 to 10). This may suggest at the same time that the parafollicular cells are completely different in structure and function from the follicle cells. Secretory granules produced in the Golgi's complex move towards the cell periphery growing in size, and finally reach the basal plasma membrane. It is probable that across the basement membrane the substance may be further poured into the circulation.

\section{Summary}

The parafollicular cells of the thyroid gland of the dog were studied by electron microscopy, and the following results were obtained.

Parafollicular cells were larger than ordinary follicle cells and have large round to oval, sometimes irregular-shaped nuclei. They were located on the follicle walls or wedged in between follicle cells but usually did not border the follicle cavity directly. They were round to oval, but when in groups they were polygonal and gathered together as buds and plates surrounded in a set with the follicles by argyrophilic fibers and capillaries. The parafollicular cells could be classified into two kinds, clear and dark cells. The latter were found to be less in number. Thyroid stimulating hormone produced no significant change-no increase of colloid droplets-in them.

At the electron microscopic level, the parafollicular cells showed the same findings as by light microscopy, but revealed the following fine structure.

1. The majority of parafollicular cells were less electron dense in the cytoplasm than follicle cells. 2. Rough-surfaced endoplasmic reticulum was poorly developed and dispersed in small numbers in the form of small vesicles and sometimes as a few thin lamellar forms together with the vesicular forms. This was one of the characteristics of this kind of cell. 3. The mitochondria were smaller in size and number than of follicle cells. They showed round to oval, partly branched profiles with ruffled outline, and had irregularly arranged cristae mitochondriales. 4. The Golgi's complex was well-developed and consisted of thin lamellar sacs, vesicles and 
vacuoles. 5. Secretory granules were found in small numbers and different in size and electron density. They were small near the Golgi's complex, probably taking their origin in the complex. 6 . No desmosomes nor complicated interdigitations were found between themselves or in between them and the follicle cell. 7. Thyroid stimulating hormone produced no significant change in their cytoplasm, also at the electron microscopic level. 8. In both the control series and experimental series no intermediate forms between the follicle cells and parafollicular cells appeared. 9. The parafollicular cells may be considered to be an independent cell species different in origin, structure and function from the follicle cells.

\section{Literature cited}

1. Arimitsu, K.: Zytologische Untersuchungen über die Interfollikularzellen der Schilddrüse der Ratte. 1. Normaler Befund. Kaibo Z., $10: 233-245,1937$.

2. Barg ma n n, W.: Thyreoidea und Parathyreoidea. Primatologia, III, TI. I, 799809 , S. Karger, Basel, 1958.

3. - Die Schilddrüse in Mö1le n d or f f's Handb. mikr. Anat., 6: Parts 2, 1-136, Julius Springer. Berlin 1939.

4. Bensley, R. R.: The thyroid gland of the opossum. Anat. Rec., $8: 431-440,1914$.

5. Be nard, W.: La thyroïde au cours de la grossesse. Rev. Franç. Endocr., 50: 395-452, 1927.

6. Boz zi, E.: Untersuchungen über die Schilddrüse. Histologie-Secretion-Regeneration. Beitr. Path. Anat., 18: 125-173, 1895.

7. Dalton, A. J. and M.D. Felix: Cytologic and cytochemical characteristics of the Golgi substance of epithelial cells of the epididymis-in situ, in homogenates and after isolation. Am. J. Anat., 94 : 171-207, 1954.

8. Dempsey, E.W.: Thyroid gland. Greep's Histology, Blakiston, New York. 1954.

9. Du mont, L.: Activité cholinestérase de cellules parafolliculaires de la thyroide. C. R. Ass. Anatomistes (Paris) 3: 480-485, 1956.

10. L : Les catégories cellulaires épithéliales de la thyroide du lapin. C. R. Soc. Biol. Paris, 152: 790-792, 1958.

11. Ehrenbrand, F.: Untersuchungen über Genese und Funktion der parafol. likulären Zellen der Schilddrüse. Z. mikr.-anat. Forsch., 60:337-354, 1954.

12. Feyrter, F.: Über die peripheren Endokrinen (Parakrinen) Drüsen des Menschen. 2. Aufl., 1-231, Wilhelm Mandrich, Wien. 1953.

13. Florentin, P. et M. Grujic: Nouvelles observations sur le mécanisme de la régénération des follicules thyroïdiens chez le cobaye. C. R. Soc. Biol. Paris, 100 : 1139-1141, 1929a.

14. - Régénération expérimentale du parenchyme thyroïdien. C. R. Soc. Biol. Paris, $102: 849-851,1929$ b.

15. - Recherches caryométriques sur la glands thyroide du Cobaye. C. R. Soc. Biol. Paris, 105 : 938-939, 1931.

16. Ga be, M.: Données histochimiques sur les cellules parafolliculaires de glande thyroïde du chien. Acta. anat., 38: 332-344, 1959.

17. - Données histologiques sur les macrothyréocytes (cellules parafolliculaires) de quelques sauropsidés et anamniotes. Acta Anat., 47:34-54, 1961.

18. Godwin, M.C.: Complex IV in the dog with special emphasis on the relation of the ultimobranchial body to interfollicular cells in the postnatal thyroid gland. Am. J. Anat., 60 : 299-339, 1936/37. 
19. H ürthle, K.: Beiträge zur Kenntnis des Sekretionsvorganges in der Schilddrüse. Pflügers Arch. ges. Physiol., 56 : 1-44, 1894.

20. Ir i e, M. : Electron microscopic observation on the various mammalian thyroid glands. Arch. hist. jap., 19: 39-74, 1960.

21. Is e $\mathrm{nschmid,} \mathrm{R.} \mathrm{:} \mathrm{Zur} \mathrm{Kenntnis} \mathrm{der} \mathrm{menschlichen} \mathrm{Schilddrüse} \mathrm{im} \mathrm{Kindesalter,}$ mit besonderer Berücksichtigung der Herkunft aus verschiedenen Gegenden im Hinblick auf die endemische Struma. Frankf. Z. Path., 5 : 205-252, 1910.

22. Kroon, D. B.: The macrothyrocytes as a functional stage of the thyroid cell. Acta Anat., 33: 76-104, 1958.

23. Kushida, H.: A new Polyester embedding method for ultrathin sectioning. J. Electron-microscopy, Japan, 9: 113-115, 1960.

24. - On an epoxy resin embedding method for ultrathin sectioning. Electron-microscopy, $8: 187-190,1959$.

25. L udwig, K.S.: Beiträge zur Schilddrüsenstructur: II. Gibt es inter-oder parafollikuläres Epithel in der Schilddrüse? Acta anat., 19: 28-50, 1953.

26. - Beiträge zur Schilddrüsenstruktur: III. Zur Frage der Makrothyreocyten in der Schilddrüse nebst histophysiologischen Bemerkungen. Acta anat., $20: 1-36,1954$.

27. Nonidez, J.F.: The origin of the "parafollicular" cell, a second epithelial component of the thyroid gland of the dog. Am. J. Anat., 49: 479-495, 1932a.

28. - Further observations on the parafollicular cells of the mammalian thyroid. Anat. Rec., 53 : 339-347, 1932b.

29. - The "parenchymatous" cells of Baber, the "protoplasmareichen Zellen" of Huerthle, and the "parafollicular" cells of the mammalian thyroid. Anat. Rec., 56 : 131-141, 1933.

30. Ohkubo, K.: On the studies of parafollicular cells (Nonidez) in the thyroid glands of dogs. Jap. J. Med. Sci., Trans. I. Anat., 5: 47-59, 1934.

31. Palade, G.E.: The fine structure of mitochondria. Anat. Rec., 114: 427-451, 1952.

32. Raymond, N.: The occurrence of parafollicular cells in the thyroid of the rabbit. Anat. Rec., 53 : 355-365, 1932.

33. Sa it o, K.: Experimental studies of the thyroid gland, with special emphasis on its parafollicular cells. Kitakanto Igaku Zasshi, 6 : 511-525, 1956.

34. Sanderson-Damberg, E.: Die Schilddrüse vom 15. bis 25 . Lebensjahr. Frankf. Z. Path., 6: 312-334. 1911.

35. Sandritter, W. und K.H. Klein: Über argyrophile Zellen in der Schilddrüse. Frankf. Z. Path., 65: 204-218, 1954.

36. Sarkar, S.K.: Hormonal control of the light cells in the thyroid gland of the rat. Anat. Rec., 139: 270-271, 1961.

37. Sato, T.: The postnatal histogenesis of the thyroid gland of the golden hamster (Cricetus auratus). Okajimas Fol. anat. jap., 33 : 225-253, 1959.

38. St ux, M. B., Thom ps on, H. Is ler and C.P. Leblond: The light cells of the thyroid gland in the rat. Endocrin., 68:292-308, 1961.

39. Sugiyama, S.: The morphogenetic and histogenetic studies of the thyroid gland of the albino rat. Nagoya Igakkai Zasshi, 50 : 1171-1246, 1939.

40. - On the postnatal development of the thyroid gland in the mouse. Jap. J. Med. Sci., 1. Anatomy, 9: 18-19, 1942.

41. - On the postnatal histogenesis of the thyroid gland of the rabbit. 1. On the glandular cells (follicle cell and parafollicular cell). Okajimas Fol. anat. jap., $23: 57-64,1950$.

42. - Studies of the histogenesis of the thyroid gland of the guinea pig. 1. The thyroid cells (follicle cells and parafollicular cells). Anat. Rec., 120: 363-378, 1954.

43. Sunder-Plassmann, P.: Nervensystem und Schilddrüse. Dtsch. Z. Chir., $252: 1-18,1939$ a.

44. - Über neuro-hormonale Zellen des Vagussystems in der Schilddrüse. Dtsch. Z. Chir., 252: 210-223, 1939b. 
45. —_ Zum Basedow-Thymus-Problem. Dtsch. Z. Chir., 252: 257-268, 1939c.

46. Takagi, K.: A cytological study on the dog's thyroid gland. Fol. anat. jap., 1: 69-100, 1922.

47. Tashiro, M.: Electron microscopic observations on the follicle cells of the dog thyroid gland. Acta anat. Nipp., 37:63, 1962 (abstract).

48. Electron microscopic observations on the parafollicular cells of the dog thyroid gland. Acta anat. Nipp., $37: 52,1962$. (abstract).

49. - Electron microscopic observations of the cyst of ultimobranchial origin found in the thyroid gland of a dog. Nagoya J. Med. Sci., 25: 159-163, 1963.

50. Van D y ke, J.H.: Behavior of ultimobranchial tissue in the postnatal thyroid gland: Epithelial cysts, their relation to thyroid parenchyma and to "newgrowths" in the thyroid gland of young sheep. Am. J. Anat., 76: 201-251. 1945.

51. Voitkevitch, A. A.: Some main properties of parafollicular cells of thyroid gland. Arch. Anat. Hist. Embri., XLIV., 52-56, 1963 (U. S. S. R.).

52. Wils o n, G.E.: The thyroid follicle in man: its normal and pathological configuration. Anat. Rec., 37: 31-60, 1927/28.

53. Yoshimura, F., T. Yonetsu and M. Nakamura: Hormonal regulation of parafollicular cell in thyroid gland. Endocrinol. Japan., 9: 284-301, 1962.

\section{Explanation of Plates}

Pieces of thyroid glands used for electron microscopy, uniformly fixed in Palade's solution, embedded and stained* by different ways.

\section{Key to Abbreviations used in Figures}

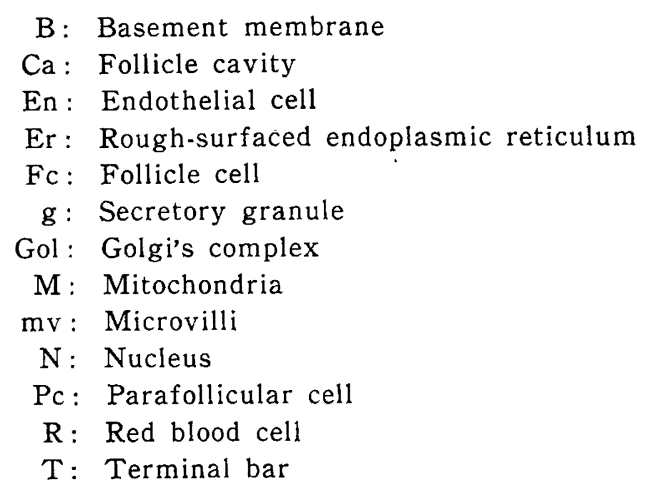

Fig. 1. 5 months old male dog (control series). Parafollicular cells (arrows) found in groups or singly between follicie cells or between follicles. They are larger than follicle cells. The chromatin reticulum is finer than that of the follicle cells and contains a prominent nucleolus. Ciaccio. Hematoxylin and eosin. $\times 560$.

Fig. 2. 15 days old male dog (control series). Parafollicular cells gather in groups and are polygonal in shape. The rough-surfaced endoplasmic reticulum is poorly developed. The mitochondria are fewer in number and smaller in size than those of adjacent follicle cells. The Golg i's complex is well-formed. The nuclei are oval in shape. * embedded in Araldite and stained with a saturated solution of uranyl acetate. $\times 5,300$. 
Fig. 3. Details of figure 2. The poor development of endoplasmic reticulum is seennear the basal plasma membrane lamellar forms are found in small numbers. The mitochondria are small in size and showed a ruffled outline, and the cristae mitochondriales are somewhat irregularly arranged. Free RNP particles found not associated with the rough- surfaced endoplasmic reticulum. The Golg i's complex is well developed. From this zone tiny secretory granules are moving towards the basal plasma membrane. In the intercellular spaces neither desmosomes nor complicated interdigitations are formed. Just along the basal plasma membrane an epithelial basement membrane is seen and continues directly to that of the follicle cells. Outside the basement membrane fibrils of connective tissue and capillary endothelial cells are found. $\times 9,900$.

Fig. 4. One day old male puppy (control series). A parafollicular cell is found singly between follicle cells. Its internal structure indicated the same appearance as that found in figure 3 . The endoplasmic reticulum and mitochondria are characteristic of the parafollicular cell. Compare them with those of surrounding follicle cells. $\times 6,600$.

Fig. 5. Details of figure 4. The cytoplasmic components of the parafollicular cell is shown. * 4 and 5 embedded in Epon and stained with $1 \%$ solution of $\mathrm{KMnO}_{4}$. $\times 13,200$.

Fig. 6. Three days old male puppy (experimental series). 18 hours after a single injection of 2 units per $100 \mathrm{~g}$ body weight of thyroid stimulating hormone follicle cells indicated tremendous dilatation of rough-surfaced endoplasmic reticulum. * embedded in Epon and stain€d with a saturated solution of uranyl acetate. $\times 8,000$.

Fig. 7. One day old male puppy (experimental series). 24 hours after a single injection of 2 units per $100 \mathrm{~g}$ body weight of thyroid stimulating hormone. The roughsurfaced endoplasmic reticulum is slightly dilated but not so much as that of follicle cells. In the left half of the cell body lamellar forms are seen and in the right half vesicular forms. * embedded in Epon, stained with $1 \% \mathrm{KMnO}_{4}$ solution. $\times 6,000$.

Fig. 8. One day old male puppy (experimental series). 24 hours after a single injection of 2 units per $100 \mathrm{~g}$ body weight of thyroid stimulating hormone. A parafollicular cell borders directly the follicle cavity. This is of rare occurrence. Terminal bars are seen. The Golg i's complex is found in the supranuclear zone and secretory granules are seen near the complex. * embedded in Epon and stained with $1 \% \mathrm{KMnO}_{4}$ solution. $\times 21,000$.

Fig. 9. 7 days old male puppy (experimental series). Two hours after a single injection of 2 units per $100 \mathrm{~g}$ body weight of thyroid stimulating hormone. Parafolliclular cells gather in radial groups. Some of the nuclei are irregularshaped like those of epithelial cells of ultimobranchial origin. This is not due to the injection of thyroid stimulating hormone. They indicate no significant change in their cytoplasmic components while neighboring follicle cells begin to dilate their rough-surfaced endoplasmic reticulums. * embedded in methacrylate and stained with none. $\times 6,000$.

Fig. 10. One day old male puppy (experimental series). 24 hours after a single injection of 2 units per $100 \mathrm{~g}$ body weight of thyroid stimulating hormone. The details of the parafollicular cell. Compare this figure with figure 5 . No significant change occurs in the cytoplasmic components. * embedded in Epon and stained with $1 \% \mathrm{KMnO}_{4}$ solution. $\times 21,000$. 
Plate I
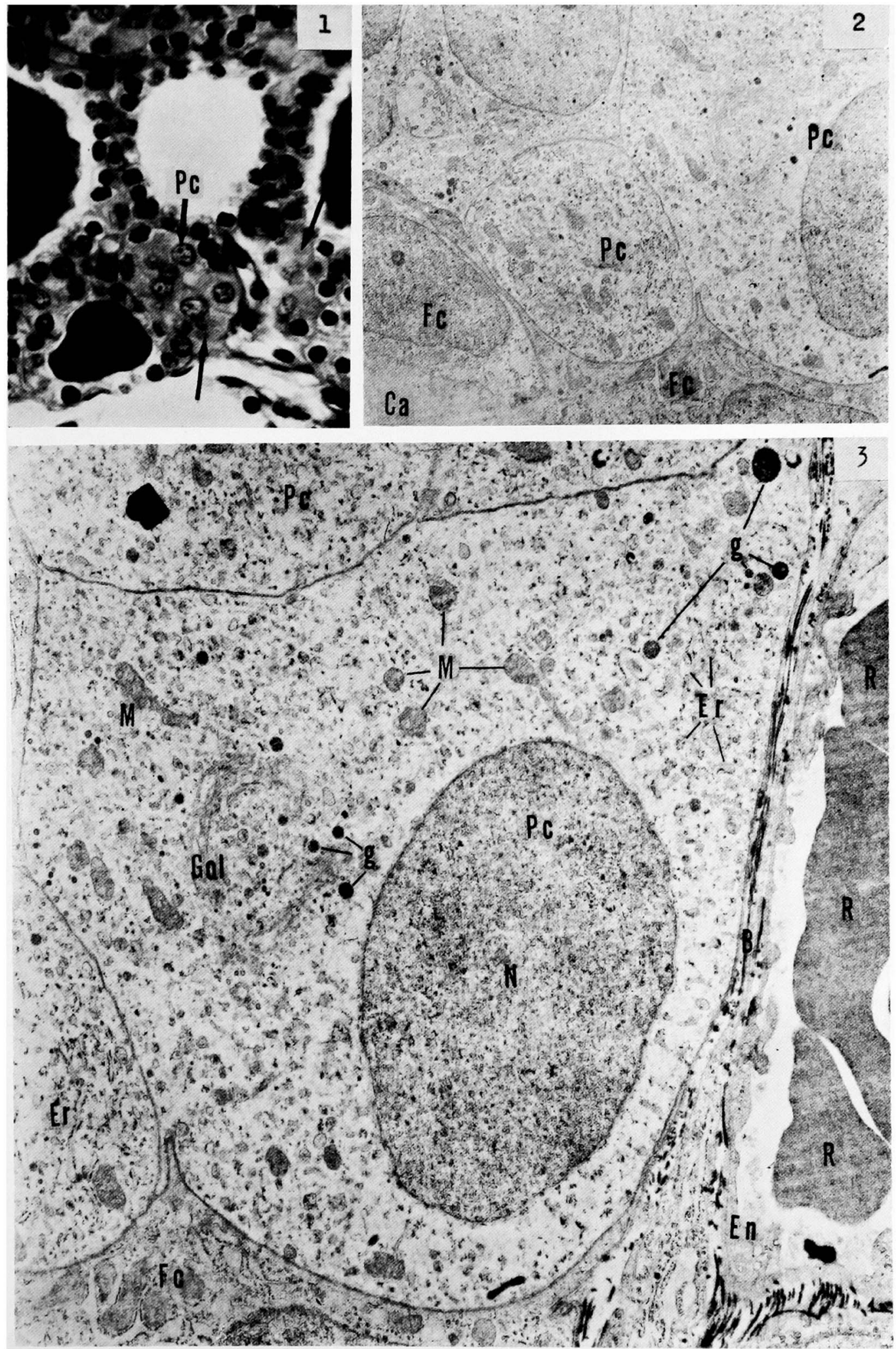

M. Tashiro 
Plate II

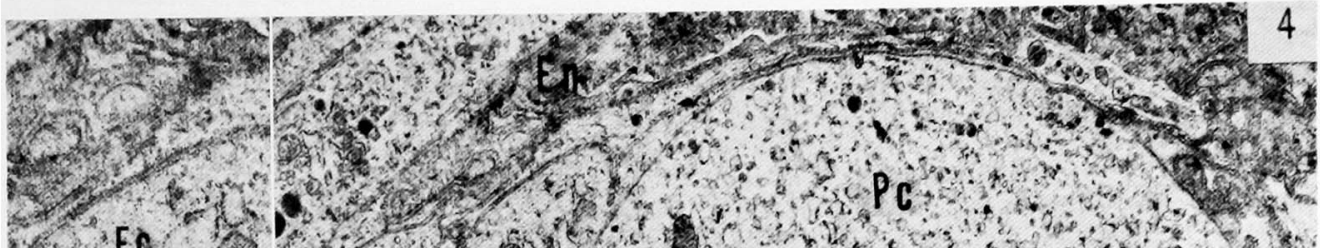

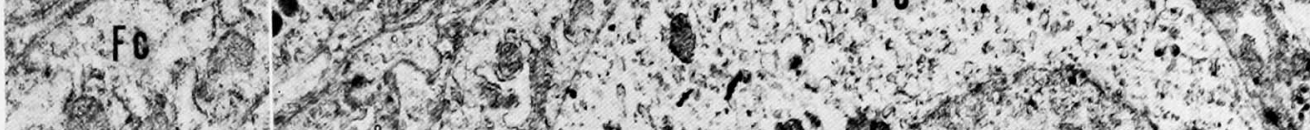

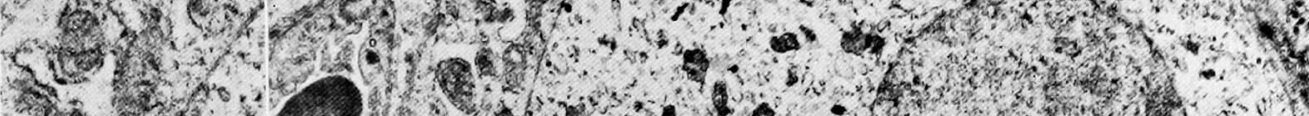

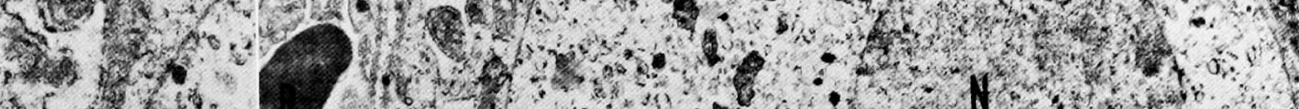

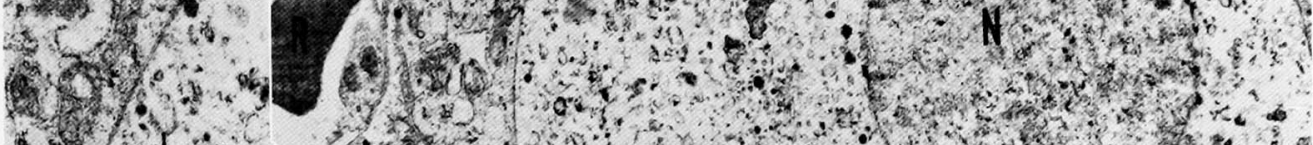

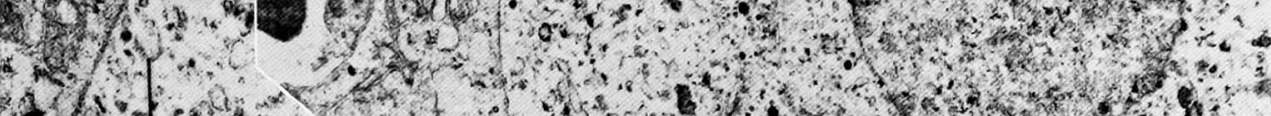

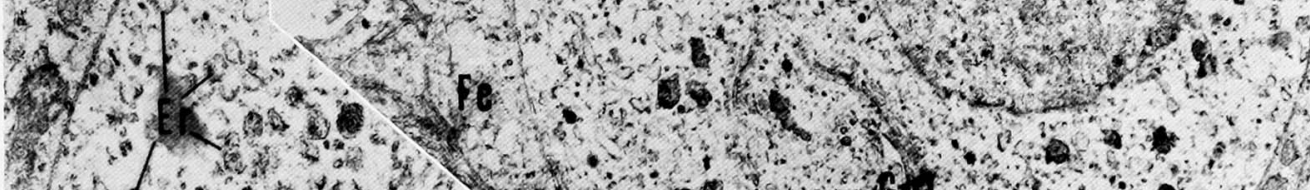
3.

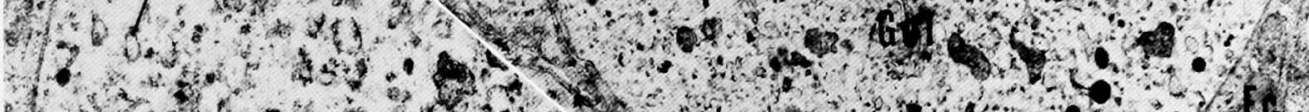

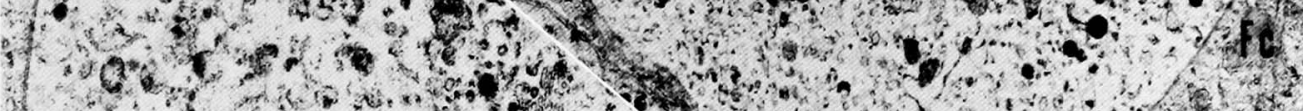

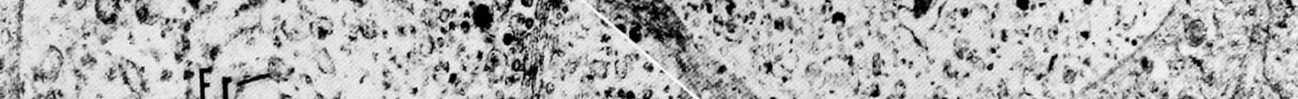

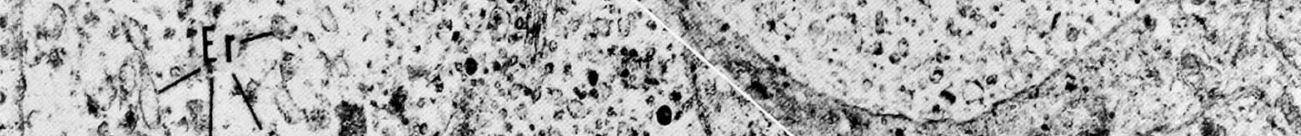

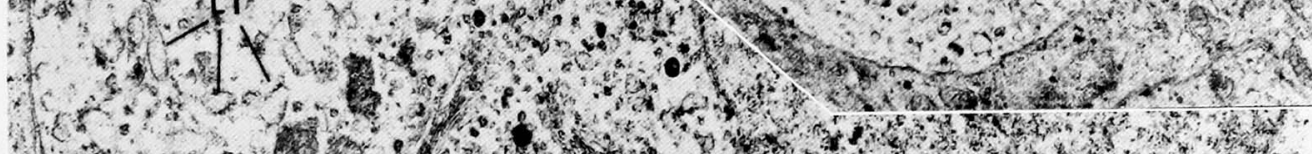

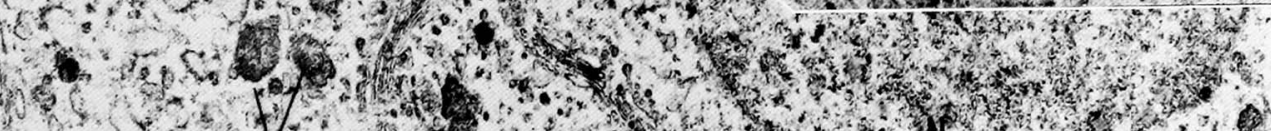

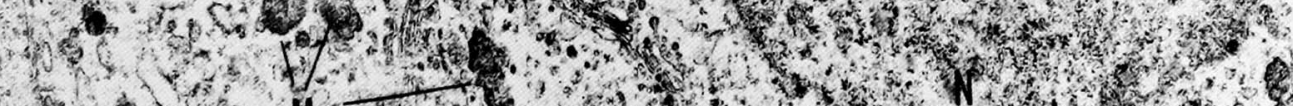

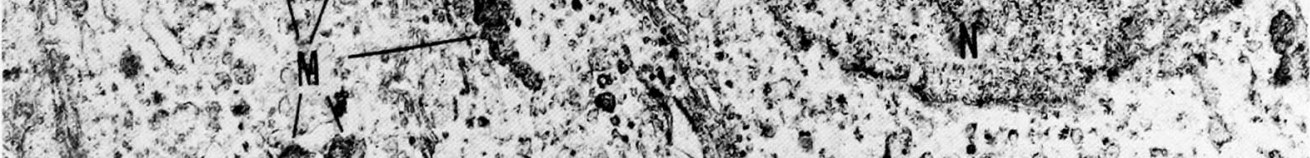

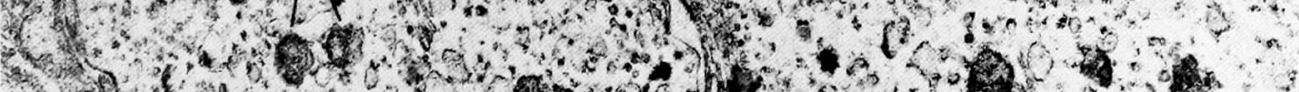

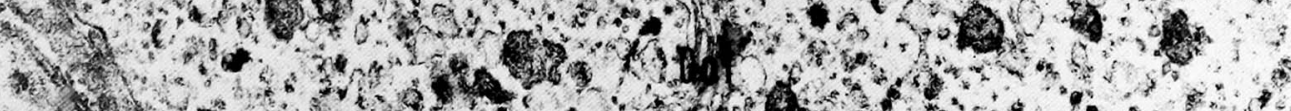

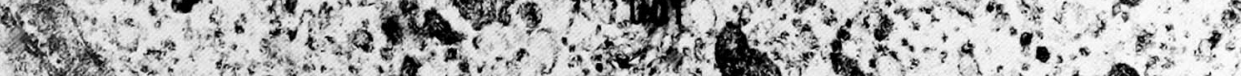

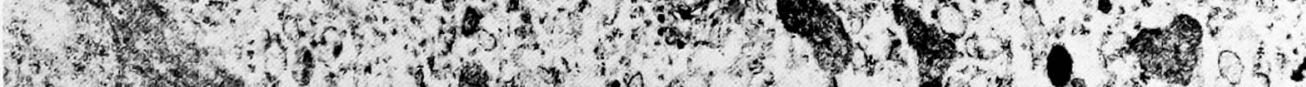
4.

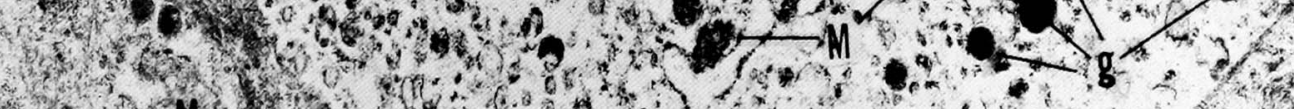

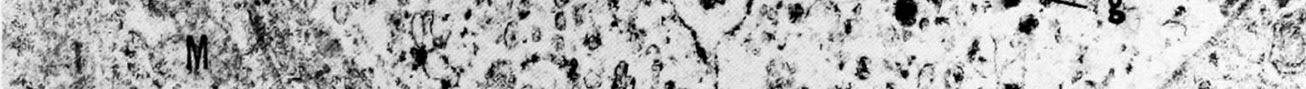

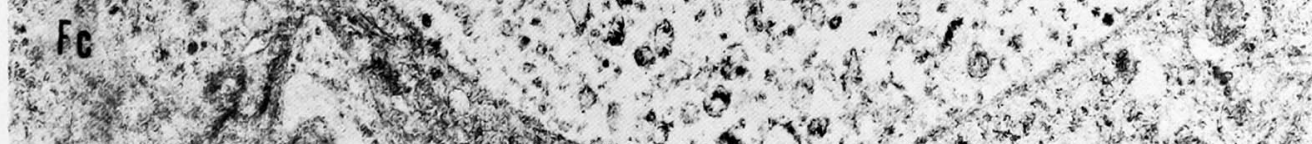

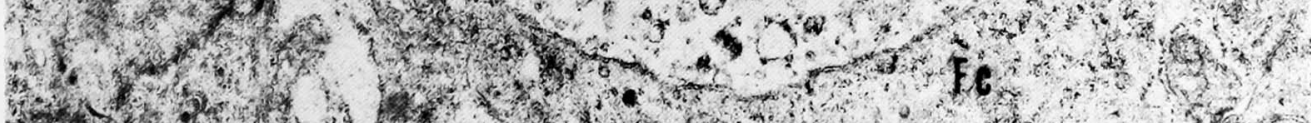

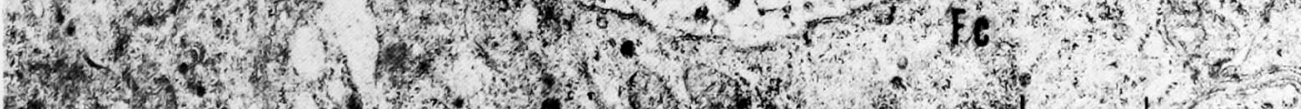

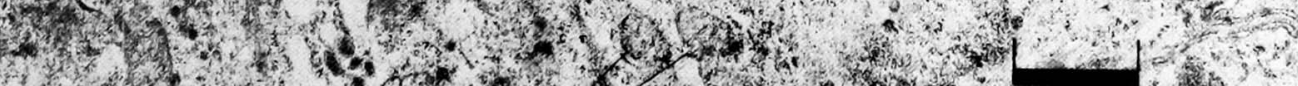

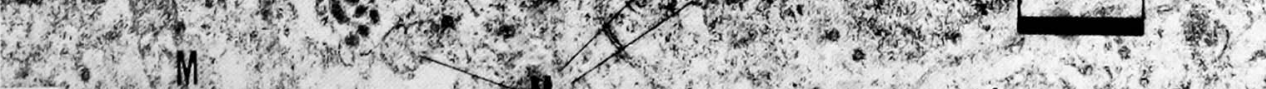

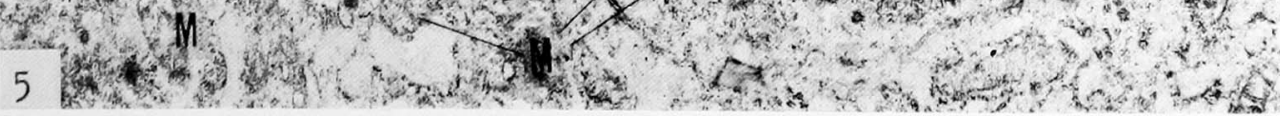


Plate III
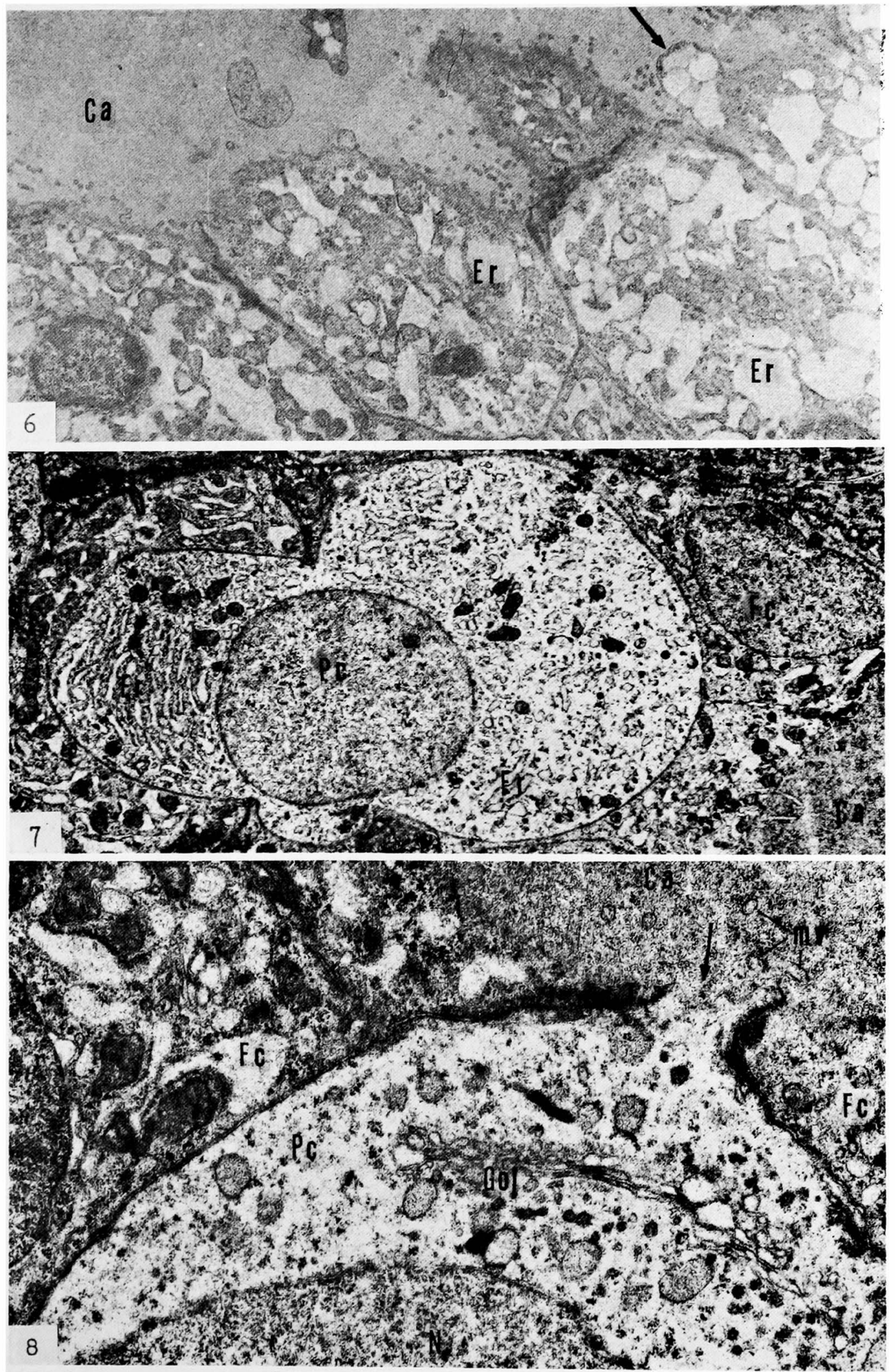

M. Tashiro 


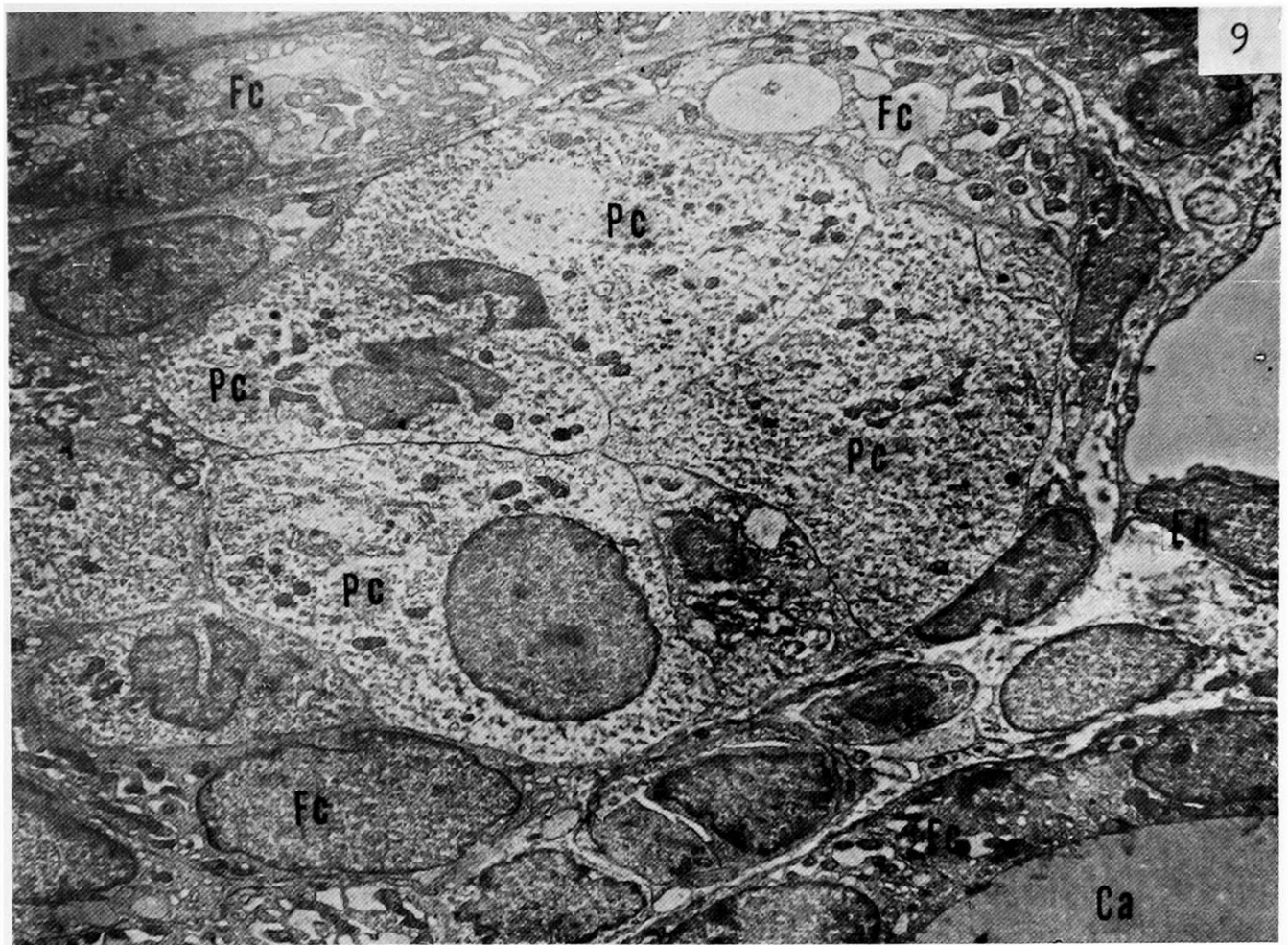

10 1.6. 1.

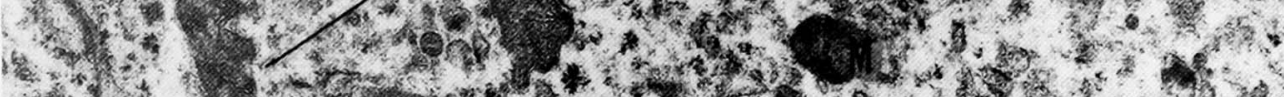

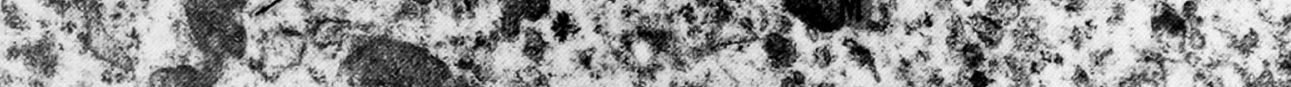

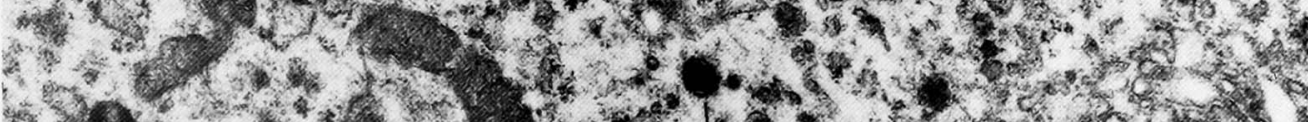

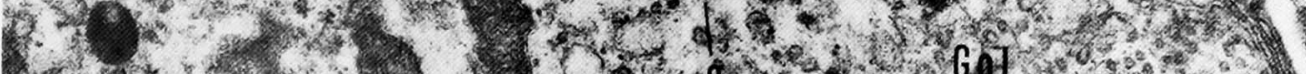
1.

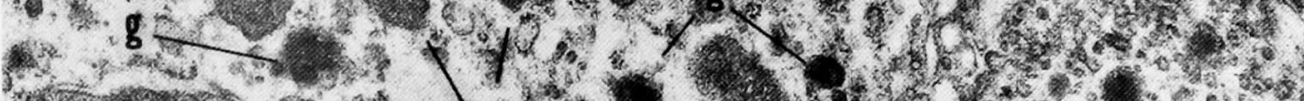
H.

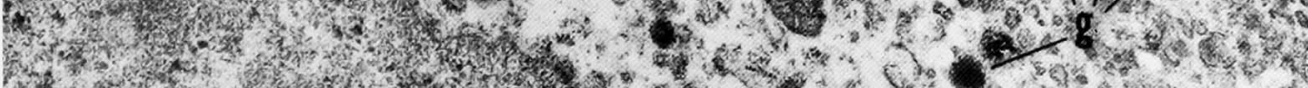

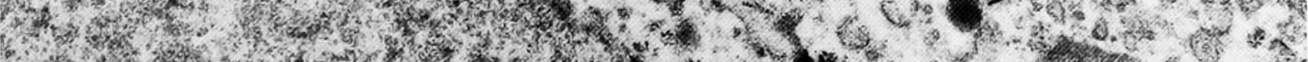

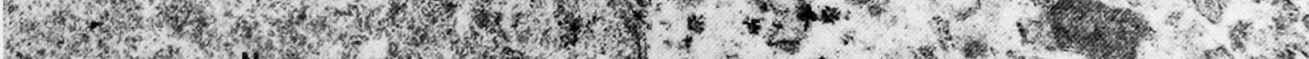

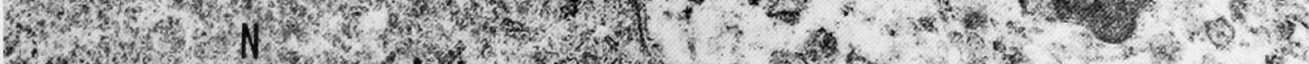

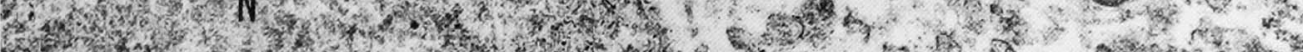

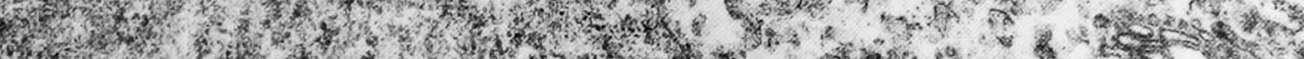

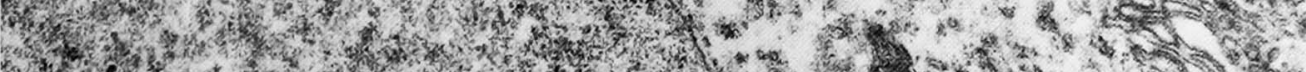

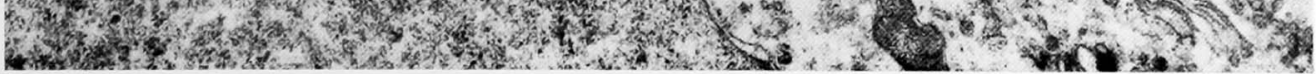

